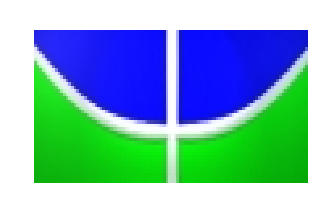

Universidade de Brasília

Centro de Excelência em Turismo

\title{
DEMONSTRAR O PERFIL DA POPULAÇÃO QUE FREQÜENTA OS RESTAURANTES VEGETARIANOS DA ASA NORTE, BRASÍLIA - DF
}

\author{
Milene Luccas Leite
}

Raquel Assunção Botelho

Monografia apresentada ao Centro de Excelência em Turismo da Universidade de Brasília como requisito parcial para a obtenção do certificado de Especialista em Qualidade em Alimentos.

Brasília, DF, junho de 2004 


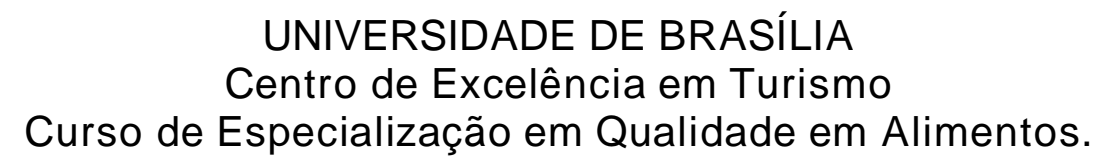

UNIVERSIDADE DE BRASÍLIA

Centro de Excelência em Turismo

Curso de Especialização em Qualidade em Alimentos.

\title{
DEMONSTRAR O PERFIL DA POPULAÇÃO QUE FREQÜENTA OS RESTAURANTES VEGETARIANOS DA ASA NORTE, BRASÍLIA - DF
}

\author{
Milene Luccas Leite
}

BANCA EXAMINADORA

Raquel Assunção Botelho, MSc.

Orientadora

Wilma Araújo, DRs.

Membro da Banca 
Leite, Milene Luccas.

Demonstrar o perfil da população que freqüenta os restaurantes vegetarianos da asa norte, Brasília-DF / Milene Luccas Leite. 2004.

48 p. : il.

Monografia (Especialização em Qualidade em Alimentos) Universidade de Brasília, Centro de Excelência em Turismo, 2004.

Orientação: Raquel Assunção Botelho.

1. Vegetarianismo; 2. Restaurante; 3. Distrito Federal. 


\title{
AVALIAR O PERFIL DA POPULAÇÃO QUE FREQÜENTA OS RESTAURANTES
} VEGETARIANOS DA ASA NORTE, BRASÍLIA - DF

\author{
Comissão Avaliadora
}

Raquel Assunção Botelho, MSc

Wilma Araújo, DRs 
AGRADECIMENTOS

A realização desta pesquisa se tornou possível graças ao apoio, gentileza e orientação de Raquel Botelho, Fabrício Condé, Valderez Alvez, Paula Alencar, aos membros da família e amigos, aos proprietários, funcionários e clientes dos estabelecimentos visitados e claro, aos autores e adeptos ao vegetarianismo, que me despertaram grande interesse e respeito pelo tema. 
"Eu costumava ter prazer ao ver as pessoas elogiando meu trabalho - mas agora isto me entristece, porque cada elogio me recorda aquilo que ainda me falta fazer. Sei que isto deve soar infantil, mas e daí?

Ontem a noite, eu dizia pra mim mesmo: $\mathcal{A}$ consciência de uma planta no meio do inverno não está voltada para o verão que passou, mas para a primavera que irá chegar. A planta não pensa nos dias que já foram, mas nos que virão. Se as plantas estão certas de que a primavera virá, por que nós - os humanos - não acreditamos que um dia seremos capazes de atingir tudo que queremos?" 


\begin{abstract}
RESUMO
Foram aplicados 184 questionários para determinar o perfil da população que freqüenta os restaurantes vegetarianos da Asa Norte, correspondendo a $15 \%$ de clientes da média de freqüência diária de todos os restaurantes, Brasília-DF e para a obtenção das informações, a pesquisa foi desenvolvida por meio de questionários aplicados em 8 estabelecimentos gastronômicos. Os resultados indicam que o perfil da clientela que freqüenta os restaurantes vegetarianos é composta basicamente por indivíduos do sexo feminino, entre a faixa etária de 31- 40 anos, que estão classificados como semivegetarianos, que freqüentam 0 estabelecimento com assiduidade e manifestaram posições conscientes e favoráveis quanto a alimentação saudável, a partir de parâmetros nutricionais modernos.
\end{abstract}

Palavras-chaves: 1. Vegetarianismo; 2. Restaurante; 3. Distrito Federal 


\begin{abstract}
In order to determine the population profile that goes to vegetarian restaurants in Asa norte, Brasília-DF and to obtain information, this work was developed through questionnaires applied in 8 establishments. One hundred and eighty four questionnaires were applied representing $15 \%$ of the average number of clients in each restaurant. The population profile is mostly based on women, from 31 to 40 years old, classified as semivegetarians and interested in healthy diet and nutritional parameters.
\end{abstract}

Key-words: 1. Vegetarianism; 2. Restaurant; 3. District Federal 


\section{SUMÁRIO}

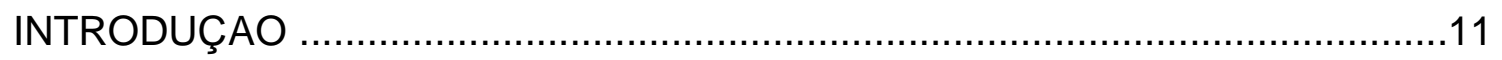

OBJETIVOS

12

REVISÃO BIBLIOGRAFICA

13

1. A DIETA DO HOMEM NA PRÉ-HISTÓRIA

13

2. HISTÓRIA DO VEGETARIANISMO

2.1 Vegetarianismo Moderno

16

3. MOTIVAÇÃO PELA DIETA VEGETARIANA

19

3.1 RELIGIOSA

19

3.1.1 Alimentação Kosher

19

3.1.2 Cristianismo

20

3.1.3 Islamismo

22

3.1.4 Budismo

22

3.1.5 Hinduismo

23 
3.1.6 Igreja Adventista do Sétimo Dia

24

3.2 ANATÔMICA E FISIOLÓGICA

24

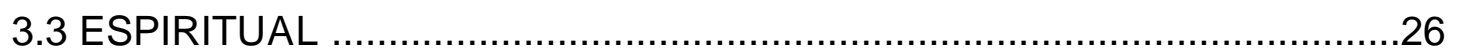

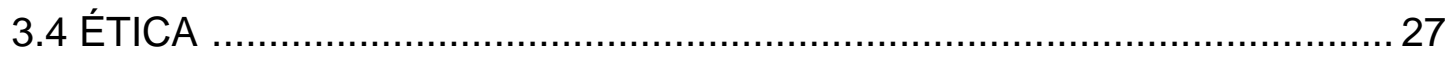

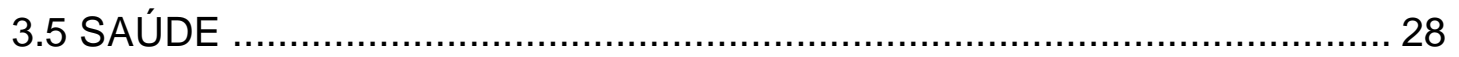

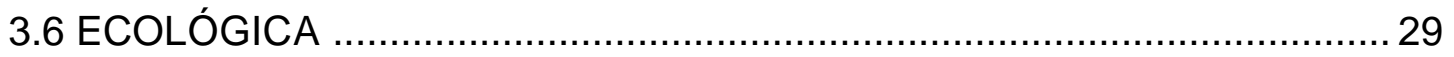

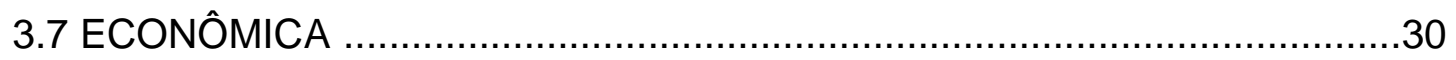

4. TIPOS DE VEGETARIANISMO

31

4.1 Vegetarianos

31

4.2 Veganismo

31

4.3 Lacto-vegetariana

32

4.4 Ovo-lacto-vegetariana

32

4.5 Ovo-vegetariana

32

4.6 Crudívora.

33

4.7 Frugívora......

33

4.8 Macrobiótica.

33

4.9 Variações do vegetarianismo.

35

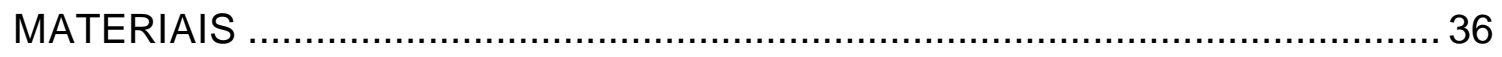

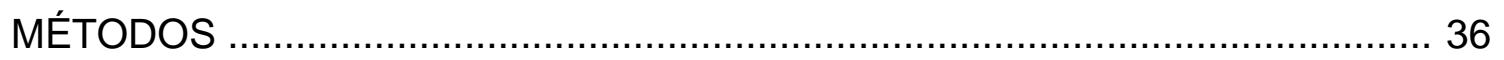


RESULTADOS E DISCUSSÃO

37

CONCLUSÃO

44

REFERÊNCIAS BIBLIOGRÁFICAS

45

ANEXOS

1- CARTA DE SOLICITAÇÃO AOS ESTABELECIMENTOS

47

2- QUESTIONÁRIO 


\section{LISTA DE ILUSTRAÇÕES}

Figura 1 - Classificação da amostragem segundo sexo, 2004 37

Figura 2 - Classificação da amostragem segundo faixas-etárias, 2004 .............. 38

Figura 3 - Classificação da opção alimentar, segundo o sexo, 2004. 38

Figura 4 - Analise da freqüência da amostra total nos restaurantes, 2004 39

Figura 5 - Classificação geral de freqüência da amostra segundo a opção alimentar nos restaurantes, 2004

40

Figura 6 - Comparação da freqüência da amostra segundo a opção alimentar, 2004 40

Figura 7 - Classificação da amostragem segundo a opção alimentar vegetariana, 2004

41

Figura 8 - Classificação da amostragem segundo as opções que justificam a escolha pela alimentação vegetariana, 2004

42

Figura 9 - Classificação da população vegetariana em relação ao tempo de adesão, 2004 


\section{INTRODUÇÃO}

O termo vegetarianismo, vem do latim 'vegetare", que significa "vida, ânimo, força, vigoro" (WINCKLER, 1997). Não se relaciona com alimentação saudável, no entanto é um tipo de regime alimentar segundo o qual o que implica em sacrifício de vidas animais não deve servir à alimentação.

Existem muitas dúvidas e mitos sobre a dieta vegetariana, desde questões ligadas ao aproveitamento de nutrientes até questões espirituais. O tipo de alimentação mostra as características próprias do indivíduo e sua vontade e objetivos imediatos, como também o seu momento, a sua filosofia de vida e os seus ideais.

A comida e a bebida influenciam a vida do indivíduo por fazerem parte das suas necessidades básicas. Porém os modos de vida foram modificados através da urbanização, da industrialização, do ingresso das mulheres no mercado de trabalho, pela elevação do nível de vida e de educação, pelo uso excessivo de automóveis e por necessidades de lazer, férias e viagens, provocando assim uma revolução no ritual alimentar que antes era realizado somente no lar, e hoje passou também a ser em restaurantes. A tendência de crescimento de refeições fora de casa favoreceu o surgimento de estabelecimento que agiliza o processo de serviços, de produção de refeições sendo variadas e com custo acessível, como os denominados self-service, que desde dos anos 50 na já existiam Europa. A preocupação dos indivíduos que freqüenta esses tipos de estabelecimento, diz respeito à obtenção de satisfação com a qualidade e a segurança dos serviços oferecidos. (FLANDRIN E MONTANARI, 1998).

É válido ressaltar que diversos fatores estão presentes no vegetarianismo, mas para um melhor entendimento das ramificações e estruturação da qual está centrado o vegetarianismo é culminante que sua história possa ser retratada, para um melhor entendimento do tema num todo e a aplicação de pesquisa em locais previamente determinados que permitam demonstrar o perfil dos freqüentadores de restaurantes vegetarianos na Asa Norte Brasília, DF. 


\section{OBJETIVOS GERAIS}

Determinar o perfil da população que freqüenta os restaurantes naturais da Asa Norte, Brasília-DF.

\section{OBJETIVOS ESPECÍFICOS}

- Identificar a freqüência dos usuários nos restaurantes;

- Classificar os freqüentadores de acordo com as modalidades do vegetarianismo;

- Identificar a justificativa dos clientes pela escolha da dieta;

- Verificar se os clientes possuem orientação nutricional;

- Relacionar o nível de satisfação da clientela em relação aos serviços oferecidos pelos estabelecimentos. 


\section{REVISÃO BIBLIOGRÁFICA}

\section{A DIETA DO HOMEM NA PRÉ-HISTÓRIA}

A alimentação vegetariana, sempre esteve presente na humanidade. De acordo com estudos, há "3,5 bilhões de anos é que surgiram os primeiros mamíferos semelhantes aos homens", (SENAC 1998) os hominídeos. Sua alimentação era influenciada de acordo com as épocas e as regiões que eles viviam e "enquanto houvesse frutas, raízes, legumes, peixes ou caça." (SENAC 1998).

Antigamente os estudiosos da pré-história caracterizavam o homem em onívoro, e escreviam, muito mais sobre a caça e a pesca do que sobre os alimentos vegetais, pois eles deixavam poucos vestígios no solo.

Cientistas modernos começaram a desenvolver métodos que possibilitaram medir as partes da alimentação do homem na pré-história e determinar os tipos de vegetais que eram mais consumidos, observaram os desgastes dos dentes dos fosseis humanóides e concluíram que durante milhões de anos, a alimentação era vegetariana. Colhiam os frutos, folhas ou grãos (FLANDRIN E MONTANARI,1998).

Um estudo analisou a anatomia e a fisiologia do homem desta época: não possuía garras, transpirava por meios de milhares de poros; não tinha dentes frontais pontiagudos; possuía dentes molares posteriores achatados, para triturar; possuía glândulas salivares bem desenvolvidas; saliva alcalina; profusão de ptialina, para digerirem cereais; apresentava trato intestinal 10 a 12 vezes o comprimento do corpo; estômago com duodeno como segundo estômago; ácido do estômago 20 vezes menos concentrado do que nos carnívoros; cólon convoluto; urina ácida com dieta carnívora, neutra ou alcalina com dieta vegetariana; mandíbula curta; e alimentava-se de cereais, vegetais, frutas e nozes (WINCKER, 1997).

Muito se questionou quando os outros alimentos passaram a fazer parte da alimentação. Com a criação de armas, redes de pesca, arcos e flechas e armadilhas, eles ampliaram a sua dieta e passaram de uma alimentação vegetariana para uma carnívora, trazendo diversas conseqüências, pois eles precisavam se organizar em grupos para atrair a presa em uma emboscada a fim de esquartejá-la. Depois ela era levada onde o grupo estava reunido para ser devorada, e com a necessidade de repartir a caça, iniciou-se um ritual de refeição. (SENAC, 1998). 
Outras conseqüências da dieta carnívora foram às dependências que elas causaram, pelo consumo de sal e de proteínas. A falta do sal teria de ser compensada de outra forma. E a falta da proteína, ocasionou o surgimento do canibalismo, pois não existia uma outra forma de compensá-la.

Mas mesmo com uma dieta carnívora, o homem já colhia grãos de trigo e fazia farinhas e com o surgimento do fogo, surgiu a arte culinária. Os alimentos deixaram de serem consumidos crus para ser assados e conservados por maior tempo. Os cereais eram torrados nas pedras, os vegetais, frutas e as carnes assadas secas ao sol ou defumadas. (SENAC, 1998).

Umas das descobertas mais importantes do homem na pré-história foi o cultivo da terra. A agricultura e a criação de animais ocorreu primeiramente no Oriente Médio e estenderam-se em outras regiões mediterrâneas.

A caça ainda era feita de forma muito precária e com o crescimento de caçadores, houve a escassez de alimentos, sendo preciso conseguir outras maneiras para se alimentar e sobreviver. Assim eles começaram a semear e colher trigo, cevada, milho, feijão, mandioca, arroz.

Passaram a montar acampamentos fixos para estarem próximos às plantações, vigiando o seu desenvolvimento e impedindo que animais e homens rivais interferissem no processo.

Este desenvolvimento influenciou os homens a possuírem novos hábitos e necessidades, iniciando o processo de civilização. Passaram a adquirir móveis para dormir, sentar e comer. Surgiram os utensílios de cerâmica, que serviam para armazenar, conservar e preparar os alimentos (SENAC, 1998).

A partir da agricultura, o camponês passou a observar o sol, a lua, e as estrelas, e a perceber as estações, as influências dos fenômenos meteorológicos sobre as plantações indicando a época de semear e de colher.

As bebidas assim como as outras preparações tiveram grande importância. As bebidas fermentadas eram fabricadas com raízes, os vinhos com framboesas, amoras e cerejas silvestres. Existiam também as bebidas à base de cevada e trigo.

Tecnologicamente, são as plantas e a agricultura que distinguem os homens civilizados do bárbaro, que se satisfaz em coletar o que encontra na natureza e em caçar. A agricultura, isto é, o sedentarismo é outra base do banquete em comum, que o nômade não conhece. Na concepção do mundo clássico, os povos que não se dedicam à agricultura, que não comem pão nem bebem vinho, são, por conseguinte, 
selvagens e bárbaros: seu alimento é a carne, sua bebida o leite (em uma espécie de projeção étnica da infância, comum a todos os indivíduos) (FLANDRIN \& MONTANARI, 1998).

\section{HISTÓRIA DO VEGETARIANISMO}

O termo vegetariano vem do latim "Vegetare", que significa dar vida. "Homo vegetus" significa homem forte, vigoroso, saudável (WINCKLER, 1997).

$\mathrm{Na}$ Grécia e na Roma Antiga, o vegetarianismo foi defendido por Pitágoras, nascido por volta de 580 a.C. É considerado pelos historiadores como o "pai do vegetarianismo".

Para Pitágoras, os homens e os animais compartilhavam a mesma alma e seu "argumento em favor da dieta sem carne tinha três "pontas" (como um triângulo): veneração religiosa, saúde física e responsabilidade ecológica" (GLEN BLIX, Dr. Phd, 1992). Razões que justificam até aos dias atuais a escolha pela dieta sem carne. Muitos escolheram a dieta, muito mais por necessidade do que por preferência. A carne era considerada um símbolo de status da classe alta e os vegetais e os cereais, considerados como comida para animais no mundo medieval.

O vegetarianismo filosófico foi forte na Grécia e na Roma antiga, sendo defendido além de Pitágoras, por Sócrates, Aristóteles, Empédocles, Plutarco, Plotino e Porfírio. Platão em algumas de suas passagens partilhava das idéias de Pitágoras. Plutarco em seu ensaio "Sobre Comer Carne", escrito em fins do século I ou início do século II, apresenta um argumento detalhado em defesa do vegetarianismo, apoiando-se nas idéias de justiça, ao tratamento humano e dos animais, (SINGER,1995). Plutarco questiona: "Que luta pela existência ou que terrível loucura vos levou a sujar vossas mãos com sangue. Vós, repito, que sois nutridos por todas as benesses e confortos da vida? Por que ultrajais a face da boa terra, como se ela não fosse capaz de vos nutrir e satisfazer?"

Alguns historiadores dizem que foi o matemático e filósofo grego Pitágoras o primeiro a praticar essa dieta durante sua permanência no Egito. Ele acreditava que comer carne "interferia no alcance da pura contemplação". Em honra a Pitágoras, europeus e americanos por quase 2500 anos até o fim do século XIX, denominavam aqueles que evitavam carne (inclusive a de aves e peixes) como pitagorianos, e só 
após a fundação da Sociedade Vegetariana Britânica em 1847 que o termo "vegetariano" foi criado.

\subsection{Vegetarianismo Moderno}

A História do Vegetarianismo moderno nasceu na Inglaterra no século IV e está diretamente ligada à religião, a partir dos seus preceitos (Blix, 1992).

O filósofo e aluno do protestante Jakob Boehmen, Thomas Tryon (1634-1703) declarou em 1657: "A voz da sabedoria... me conclamou ao isolamento e autonegação... Eu me dispus a somente água para beber e abandonei todo o tipo de carne ou peixe, confinando-me a uma vida abstêmia e de negação do ego." Em seu livro publicado em 1691, O Caminho da Saúde, lido por diversos pensadores da época, ele advogava uma dieta vegetariana influenciando Benjamin Franklin (17061790) a se tornar um "Tryonista" por algum tempo. (Blix,1992)

Tryon influenciou um famoso médico de Londres, o Dr. George Cheyne (16711743), que decidiu por necessidade seguir a dieta vegetariana de Tryon, levando-o a publicar em 1724 o "Ensaio sobre Saúde e Vida Longeva" recomendando uma dieta sem carne.

Cheyne com seu ensaio converteu o fundador da Igreja Metodista John Wesley, Pope, Swift, Hume e vários amigos. Assim outros pensadores e escritores da Inglaterra passaram a elogiá-lo e a praticar a dieta vegetariana, espalhando controvérsia entre os afiliados da Sociedade Real de Londres.

O Presidente da Sociedade Real, Sir Isaac Newton, convidou o Dr. Antônio Cocchi de Florença na Itália. Cocchi se convenceu da argumentação Cheyne e em agosto de 1745 em Floresça realizou uma palestra sobre as virtudes da dieta "Pitagórica". Leonardo Da Vinci (1452-1847), se manifestou declarando que "Eu tenho desde criança abandonado o uso da carne e um dia os homens verão o assassinato dos animais da mesma forma como vêem hoje o assassinato dos humanos" (BLIX,1992).

O livro de Cheyne permaneceu popular sendo impresso 46 anos depois influenciando o Dr. William Lambe (1765-1847) que dizia: "O uso da carne dos animais é um desvio das leis de sua natureza, e é uma causa universal de doenças e mortes prematuras". Este que por sua vez influenciou o Dr. William Cowherd (1763-1816), um dissidente da Igreja da Inglaterra. Ao romper com a igreja, 
Cowherd, fundou sua própria seita em Manchester, a Igreja Cristã Bíblica. Acreditando fielmente pregava a dieta do Gênesis 1:29 sendo requisito para a filiação à igreja, a dieta vegetariana por seis meses no mínimo.

William Medcalfe (1788-1862) um evangelizador ativo da Igreja, liderou um grupo de pessoas para uma jornada até a Filadélfia sem que renegassem ao vegetarianismo. Escreveu o primeiro livro sobre vegetarianismo nos EUA, Abstinência de Carne Animal, convertendo Syvester Graham (1794-1851) que após freqüentar a igreja passou a recomendar e a realizar palestras sobre a dieta vegetariana. (BLIX,1992)

Graham fez parte de um momento histórico da alimentação americana, marcada com as reformas alimentares que surgiram a partir de 1830, com o objetivo de tentar disciplinar e limitar o consumo alimentar da época que era farto, e devido a economia de subsistência, que com o progresso dos transportes, se transformou em economia de mercado, estimulando o desenvolvimento do comércio, da indústria e do consumo. Graham se inspirava na teoria vitalista que circulava na França. Segundo ele, "a nova ciência da fisiologia demonstrava que a bebida era responsável por uma excessiva estimulação do sistema nervoso, a qual minava essa força vital e coloca o corpo à mercê da doença, da astenia e da morte. Graham estendeu rapidamente, à atividade sexual e ao consumo de carne e especiarias, o que Ihe permitiu afirmar que o vegetarianismo e a castidade se baseava em verdades fisiológicas científicas" (FLANDRIN e MONTANARI, 1998). Suas idéias faziam parte da tendência intelectual romântica e contava com o apoio de outros americanos como William Alcott, Bronson Alcott, Louisa May Alcott e o Dr. Russel Trall, que juntos fundaram a Sociedade Vegetariana Americana, que não resistiu por muito tempo.

Ellen White, uma das fundadoras da igreja Adventista do Sétimo Dia, era defensora da dieta vegetariana. O Vegetarianismo americano surgiu com a preocupação com a Guerra Civil, pois em 1866, a igreja abriu um instituto de saúde em Battle Creek em Michigan, mas dependia de uma equipe de médicos treinados. A igreja apoiou e estimulou um jovem adventista e adepto do vegetarianismo nos estudos no curso de medicina. Este jovem, John Harvey Kellogg, se tornou diretor do instituto Battle Creed Sanitarium, e conseguiu elevar a fama da clinica mundialmente e a fabricar cereais para café da manhã. 
Ao ser reorganizada a Sociedade Vegetariana Americana em 1886, Kellog foi honrado porta voz principal e seu livro Dieta Natural para o Homem, passou a ser um ícone sobre o vegetarianismo americano mudando o culto para uma prática científica, ainda não convencida.

No século XIX, com a preocupação de saúde e tratamento humano e dos animais, surgiram alguns pensadores vegetarianos como o poeta Percy Bysshe Shelley, Henry Salt que escreveu o livro Direitos dos Animais e George Bernard Shaw, que afirmava que por razões éticas deveríamos nos tornar vegetarianos, não fosse o fato de o gênero humano não poder existir sem alimento animal.

$\mathrm{Na}$ década de 70, três linhas de argumentação foram responsáveis pela retomada do vegetarianismo. Saúde, ecologia e preocupação com os animais. A saúde é almejada através de uma alimentação saudável, procurando se basear na ciência. A ecológica diz respeito à agricultura e a quantidade de pastagem de gado e que deveriam ser aproveitados para o plantio. Por uma questão ética, ao se observar a preocupação a com a fome mundial, em preservar a terra, em conservar energia, mais pessoas aderem ao vegetarianismo. Segundo a SVB, Sociedade Vegetariana Brasileira, atualmente há uma estimativa de que $10 \%$ da população dos EUA e da Europa são vegetarianos. 


\section{MOTIVAÇÃO PELA DIETA VEGETARIANA}

Como foi citado anteriormente a história do vegetarianismo possui ligações com questões religiosas e espirituais, porém há outros fatores motivadores que influenciam um indivíduo ou uma comunidade a optar pela dieta vegetariana.

\subsection{RELIGIOSA}

Muitas religiões adotam a dieta vegetariana com o propósito de almejarem a ascensão espiritual e o respeito à vida dos animais. Segundo alguns mestres antigos, a carne transfere energias densas e inferiores para aqueles que a consomem.

\subsubsection{Alimentação Kosher}

Os judeus seguem proibições do consumo de determinadas carnes feitas por Moisés que foram reveladas por Deus no Monte Sinai. De acordo com Moisés, as carnes de animais "impuros" devem ser evitadas. Mas existem certos critérios de avaliação das espécies que podem ser consumidas, como as espécies que ruminam e as que possuem o "casco fendido", partindo em duas unhas; devem possuir patas se forem terrestres; e barbatanas e escamas se forem aquáticos. O porco, apesar de possuir casco fendido e partindo em duas unhas, eles não ruminam, sendo um exemplo de carne proibida. Philo, um filósofo judeu do século I, dizia que Deus proibiu a carne de porco e mariscos porque essas eram as carnes mais saborosas, assim restringiria os desejos e prazeres do corpo.

Mas ainda que o animal seja puro ou "Kasher", ${ }^{1}$ a Bíblia afirma que é proibido atentar sobre a vida dos seres vivos, sendo válido para homens e animais, não podendo o homem matar um animal ou um animal matar outro animal. O sangue simboliza a essência do homem, e por isso os rabinos estabeleceram regras e rituais

\footnotetext{
1 "Kosher" -Todo tipo de comida própria para ser ingerida; palavra derivada de 'Kasher', em Hebraico, que significa "bom" e "próprio".

"Terayfa" significa que a comida não é "kosher", e essa palavra significa rasgado e seu uso vem do livro do Êxodo (22:30) que não se deve comer carne que tenha sido "rasgada" por outro animal, ou seja, não se deve comer um animal morto por outro. Posteriormente essa palavra foi extrapolada para definir aquilo que não se deve comer.
} 
a fim de que as carnes fossem consumidas se fosse extraído todo o seu sangue. $O$ "shochet", é uma pessoa treinada para o ritual judeu, que para inicia-se cortando a jugular do animal que morre instantaneamente e posteriormente se retira todo o sangue. Essa regra é válida também para as aves, proibindo a água quente que serve para retirar as penas, pois a água quente coagula o sangue.

\subsubsection{Cristianismo}

O cristianismo possui influencias dos judeus, aderindo aos jejuns como purificação do corpo e do espírito. E muito questiona se Jesus condenava o consumo de carnes, mesmo existindo citações na Bíblia que estimulam a reflexão por partes daqueles que seguem os preceitos. Uma das citações da Bíblia que serve de argumento para os adeptos do vegetarianismo está escrita no livro do Gênesis:

"E Deus os abençoou e disse: Eis que vos dei as ervas que dão sementes sobre a terra e sobre todas as árvores que encerram em si sementes do seu gênero, para que vos sirvam de alimento. $E$ a todos os animais da terra e a todas as aves do céu e a tudo o que se move sobre a terra, e em que há alma vivente, toda a erva verde Ihes será para mantimento". (Gên. 1:28-31)

Os vegetarianos acreditam que Jesus era contra o consumo de animais como fonte de alimentação e são vários os santos e religiosos da comunidade cristã primitiva que foram abstêmios de carne. O escritor, teólogo, polemista e moralista, Tertuliano (155-255 DC) e Clemente de Alexandria (150-215 DC), pensador e responsável pela escola catequética de Alexandria e São João Crisóstomo (347-407 DC), ensinaram aos seus discípulos que evitando a carne, aumentariam a disciplina e a força para resistir as tentações. (BLIX,1992)

Na Europa os monastérios no período da Idade Média até o Século XVIII, consideravam a abstinência de carne muito importante. Segundo Janet Barkas (1975) em The Vegetable Passion:

“Jejum e abstinência de carne eram estimulados como um meio de aumentar a força da vontade em detrimento da carne mortal e dos desejos. Entretanto, a carne bovina era o tabu, não a de peixe." 
São Bento, monge italiano que fundou a ordem beneditina em Montecassino na Itália, exemplificou sua posição na Regra:

"Além disso, que o uso da carne seja concedido aos doentes que estiverem muito fracos para recuperar as forças, mas quando estiverem convalescidos, que todos se abstenham de carne como sempre".

Os Cistercienses, membros de uma ordem fundada em 1098 formadas por monges e freiras cristãs que seguem a regra beneditina, eram abstêmios de carnes por considerá-la um bem mundano com atrativos de sabor. Assim, excluindo-a da dieta, o monge se dedicaria com maior intensidade às questões espirituais e divinas. Atualmente em determinadas regiões como na Argentina e África, essa regra não é seguida à risca devido as dificuldade de se encontrar outros alimentos.

Os Trapista são membros da divisão da Ordem Cisterciense, a Ordem Reformada da Estrita Observância, que originou a La Trappe na França. A dieta vegetaria não é pré-requisito, mas ainda há adeptos e possuem o gosto pelos alimentos naturais.

As Carmelitas, membros de uma ordem de freiras constituídas de austeras regras, fundada em 1452 e, a seita mística Essênios, se vestia de branco e foram criadas em Monte Carmelo em Israel eram adeptos da dieta vegetariana.

Outros lideres do cristianismo como São Francisco de Assis, Santa Clara e o patriarca do País de Gales, São David, não comiam carne pois motivavam a autodisciplina, mas a carne de peixe não era proibida.

“...Por fim eles se reúnem à mesa. Todos recuperam e refrescam os membros exausto compartilhando o jantar, entretanto, não havia excessos, pois o exagero, por mais que fosse só de pão, engendra a auto-indulgência; mas naquela refeição, todos jantavam de acordo com as várias condições de seu corpo ou idade. Eles não servem pratos de diferentes sabores, nem tipos de alimentos mais ricos: seu alimento é, de fato, pão e ervas temperadas com sal, e matam a sede com uma espécie de bebida temperada..."

$\mathrm{Na}$ Inglaterra, os monastérios, se tornaram centros de aprendizagem de arte, florescendo de forma rentosa. Os abades passando a assessorar os governantes do 
país e recebendo doações de terras e dinheiro. Com o crescimento da igreja, as virtudes primitivas do monasticismo foram gradualmente adulteradas e as regras estritas sobre os regulamentos de obediência e pobreza ignoradas. Como a carne era consumida apenas pelos enfermos, passou a ser consumida por todos até a proibição de uma bula papal que criou uma sala entre a enfermaria e o refeitório, chamada de "misericórdia" onde a carne era servida livremente, que mais tarde também se tornou proibida. Mas o papa, percebendo que não poderia reprimir as preferências dos monges, liberou novamente a "misericórdia", desde que houvesse uma separação, ou seja, os monges vegetarianos deveriam se alimentar em outro lugar.

\subsubsection{Islamismo}

O Islamismo, por exemplo, não adota a dieta vegetariana e nem a considera como necessidade religiosa, mas o alcorão, o livro sagrado da religião, recomenda não comer carnes de animais mortos, carnes e sangue. Maomé pregava a gentileza com os animais e um profeta que o sucedeu, aconselhava os seus discípulos: "Não transformem seus estômagos em sepulturas de animais".

\subsubsection{Budismo}

Já o Budismo vem praticando o vegetarianismo por 2500 anos. Os budistas pregam o respeito aos animais. Buda disse: "feliz seria a terra se todos os seres estivessem unidos pelos laços da benevolência e só ingerissem alimentos que não implicam derramamento de sangue. Os dourados grãos, os reluzentes frutos e as saborosas ervas que nascem para todos bastariam para alimentar e dar fartura ao mundo". 


\subsubsection{Hinduismo}

O Hinduísmo também possui princípios vegetarianos datados de 5000 anos considerando a vaca como um animal sagrado. Nas escrituras Védicas que pregam a abstinência de carnes, um sistema médico indiano a Ayurveda, divide os alimentos em três categorias, as gunas ou as qualidades da matéria: tamas, rajas e satva. Cada tipo de alimento possui características que serão destinados para gerar sutileza ao corpo, as emoções e os pensamentos. (BONTEMPO, 2003)

Os alimentos tamas bloqueiam a percepção espiritual, enfraquece os pensamentos, intoxicam o corpo, dificultando a percepção da sutileza das coisas. São normalmente alimentos com aparência, odores fortes e sabores fortes, condicionados, secos, defumados, muito condimentados, gordurosos como os embutidos, salames, salsichas, vísceras animais, camarões, mariscos, carnes vermelhas etc.

Os alimentos Satva favorecem a sensibilidade espiritual, purificam o corpo, suavizam a mente e facilita a meditação. São eles: Trigo, arroz, cevada, centeio, trigo sarraceno, milho, leite fresco, frutas suaves, mel, néctares.

Os rajas são os alimentos estimulantes que favorecem o trabalho da mente, provocando reações e tonificando. São os temperos naturais, mas fortes, como a pimenta o alho, a cebola, a assa-fétida, o gengibre, o café, chás, estimulantes e bebidas alcoólicas.

Vários grupos hinduístas, como os adeptos de Krishna, os Hare Krishna seguem uma alimentação baseada na Lei de Deus, ou Dharma, caracterizada pela harmonia, sobriedade, regularidade e está voltada para o bem-estar e o bom funcionamento do organismo. Deve ser composto por produtos leves, nutritivos, saudáveis, frescos, naturais, orgânicos, da estação, bonito, colorido e rico em energia podendo ser plantados e brotados. Primam pela qualidade do alimento e não pela quantidade. 


\subsubsection{Igreja Adventista do Sétimo Dia}

Os adventistas do Sétimo Dia compõem um grupo religioso que prega um estilo de vida radical diferente do estilo de vida dos norte-americanos e com normas alimentares baseadas no versículo 11 do Levítico, da Bíblia, que mais tarde Ellen G. White, que foi a fundadora do grupo modificou as normas e difundiu ativamente suas idéias a partir de 1863.

“Estimulantes como chá, café e cigarro são considerados nocivos à saúde. O álcool é condenado. Animais que vivem na água e possuem nadadeiras e escamas foram aprovados. Animais ruminantes e que possuem o casco dividido são considerados puros e próprios para a alimentação; os demais são tidos como impuros e impróprios para o homem. Vegetais, frutas, grãos, leite, alguns laticínios e ovos são considerados próprios para o consumo." (McGEE, 1986)

Além de White, Harvey Kellogg também é um ícone na história da alimentação americana e divulgador dos preceitos adventistas. Os adventistas financiam hospitais nos EUA e onde suas igrejas se instalam e realizam pesquisas de saúde entre seus membros procurando evidenciar a qualidade de vida dos indivíduos adeptos às normas alimentares adventistas.

\subsection{ANATÔMICA E FISIOLÓGICA}

Comparando as características anatômicas e fisiológicas dos animais carnívoros, herbívoros e frugívoros, entende-se que a dieta frugívora e herbívora é a mais adequada ao homem.

Os animais carnívoros possuem garras, não possuem poros, transpiram pela língua, possuem dentes frontais alongados, fortes e pontiagudos para rasgar a carne; não possuem dentes molares posteriores para triturar alimentos; possuem glândulas salivares pequenas na boca (glândulas bem desenvolvidas são necessárias na pré-digestão de cereais e frutas), e possuem a saliva ácida; não possuem a ptialina uma enzima responsável pela pré-digestão dos cereais, possuem o trato intestinal 3 vezes o tamanho do corpo, para que a carne em decomposição possa ser eliminada rapidamente; possuem o estômago simples e arredondado, 
apresentam forte concentração de ácido clorídrico no estômago, para digerir a carne, possuem cólon liso, a urina é ácida, a mandíbula é alongada para frente e se alimentam de carne.

Os animais frugívoros não possuem garras, transpiram por meio de milhares de poros, não possuem dentes caninos frontais pontiagudos, possuem os dentes molares posteriores são achatados, para triturar; possuem glândulas salivares bem desenvolvidas, a saliva é alcalina, possuem profusão de ptialina, para pré-digerir cereais; possuem o trato intestinal 10 a 12 vezes o comprimento do corpo, o estômago tem o duodeno como segundo estômago, o ácido do estômago é 20 vezes menos concentrado que nos carnívoros; o cólon é convoluto, a urina é alcalina, possuem mandíbula curta e se alimentam de frutas e nozes.

Os animais herbívoros não possuem garras, transpiram por meio de milhares de poros, não possuem dentes caninos frontais pontiagudos, possuem dentes molares posteriores achatados e para triturar, possuem as glândulas salivares bem desenvolvidas; possuem a saliva alcalina, possuem profusão de ptialina, para prédigerir cereais; o trato intestinal é 10 a 12 vezes o comprimento do corpo, o estômago em três ou quatro compartimentos, o ácido do estômago é 20 vezes menos concentrado que nos carnívoros; possuem cólon convoluto, sua urina é alcalina, a mandíbula é levemente alongada e se alimentam de grama, ervas e plantas.

De acordo com as características anatômicas e fisiológicas desses animais, percebe-se que os animais herbívoros e frugívoros são os que mais se assemelham ao homem. Pois o homem não possui garras; transpira por meio de milhares de poros, não possui dentes caninos frontais pontiagudos e os dentes molares posteriores são achatados para triturar. As glândulas salivares são bem desenvolvidas e a saliva é alcalina; possuem profusão de ptialina para pré-digerir cereais, o trato intestinal 10 a 12 vezes o comprimento do corpo, e o estômago possui um duodeno como um segundo estômago e a sua ácidez 20 vezes menos concentrado do que nos carnívoros; o cólon é convoluto, a urina é ácida com uma dieta carnívora e neutra ou alcalina com a dieta vegetariana, a mandíbula é curta, e ele deveria se alimentar de cereais, vegetais, frutas e nozes.

Um ponto a ser destacado é o fato de que os carnívoros possuem o intestino com aproximadamente três vezes o comprimento do corpo, isso faz com que a digestão seja mais rápida, eliminando tudo o que não for absorvido. Já o homem por 
possuir o comprimento do intestino 12 vezes maior, faz com que a digestão dos alimentos seja lenta e no caso da carne em especial, por ela por já estar sofrendo o processo de decomposição desde a morte do animal, continua a se decompor no intestino humano, liberando toxinas causando problemas sérios de saúde. (WINCKLER,1997)

\subsection{ESPIRITUAL}

O ato de se alimentar não visa somente a obtenção de saúde física, visa também a busca pela espiritualidade, pela essência de uma alma pura, estando diretamente ligado à consciência. Isto não quer dizer que: "uma alimentação natural não torna alguém mais espiritual, mas é certo que o corpo em estado equilibrado favorece o desenvolvimento mental e espiritual" (COURY, 1999).

Os adeptos por uma dieta vegetariana, ou até mesmos os adeptos de outras dietas, acreditam que os alimentos possuem sua própria energia, assim como a energia do próprio indivíduo e como os prepara, influencia na harmonização com as leis universais. Leis estas que podem ter relação com ciclo econômico e ecológico. O consumo dos alimentos pode interagir com estes mecanismos em nível energético, levantando a questão da validade de alguns "benefícios" para a evolução espiritual. O conhecimento da procedência seria essencial para o consumo dos alimentos e a combinação dos mesmos a nível nutricional.

A preservação das leis da natureza, a conservação das espécies e da vida, tem como premissa que não se destrua a vida dos animais. Os espiritualistas, assim como os evolucionistas, acreditam que os animais possuem alma e manifestam simpatia, medo, irritação, impaciência, amor, vaidade, e inteligência. O ato de matar um animal, para satisfazer a fome, é considerado uma atitude de crueldade e de egoísmo incentivando desta forma um crime também para o próprio homem.

Os animais ao perceberem o momento de sua morte, sofrem com as sensações de medo, de revolta, raiva, além das dores causadas pelo próprio ato de violência. Eles transmitem essas vibrações malignas, para aqueles que irão consumir a carne. Essas vibrações contribuem para que o corpo astral se torne grosseiro, agressivo, propenso a vícios, a excitabilidade sexual, a compulsividade e atitudes violentas. 
Segundo Mary Winckler (1997), "Do ponto de vista do aperfeiçoamento do corpo humano com vistas à realização espiritual, verdadeira finalidade de nossa existência, a carne também é totalmente rejeitada, seja porque não é um alimento de propriedades intrínsecas que favoreça a harmonia, o equilíbrio, o ritmo e a perseverança, que o espírito requer e busca, seja porque a compaixão, qualidade inerente ao florescer espiritual, também a exclui. Por tudo isto, ou simplesmente pelo motivo mais pessoal, porém também legítimo, de ter-se uma existência mais saudável e duradoura, a carne é invariavelmente desaconselhada".

\section{4 ÉTICA}

Segundo Ferreira (1993), ética se refere ao "estudo dos juízos de apreciação referentes à conduta humana, do ponto de vista do bem e do mal."

Logo, os indivíduos vegetarianos são éticos ao serem fiéis a determinadas idéias e condutas dentro daquilo que eles acreditam, a exclusão da carne animal em sua alimentação, por exemplo. Para eles, o consumo da carne animal é totalmente antiético, uma vez que os animais sofrem crueldades. Sendo criados em espaços reduzidos, superlotados, confinados, passando fome e sede, sendo expostos a doenças em decorrência de falta de higiene de cuidado do local. A forma de abate que muitas vezes ainda primitiva e violenta, levando os animais ao sofrimento, esquartejando-os, esfolando-os, queimando-os e depenando-os ainda vivos.

Um outro fator ligado também a essa questão da carne animal se refere à quantidade de extensão de terra utilizada para a pastagem dos animais. Trata-se de um fator econômico, ecológico e de direitos humanos. Considerando que essa mesma quantidade de terra utilizada para este fim poderia ser dedicada à lavoura, aumentando a produção de alimentos saudáveis e assim colaborando com a diminuição da fome dos indivíduos. Partindo dessa observação conclui-se ser antiético o consumo de carne e um hábito ostensivo e inaceitável, estando claro que todos os nutrientes necessários para a sobrevivência são encontrados nos alimentos oriundos da terra. 


\subsection{SAÚDE}

A dieta vegetariana ainda se encontra em processo de aceitabilidade e validade pela academia científica, que resiste em estudá-la. Apesar disto, os vegetarianos aceitam o desafio de conciliar seus princípios filosóficos com a validade da dieta no meio científico. Alguns cientistas já vêm conduzindo estudos e evidenciaram o valor da dieta para a saúde, mas ainda há muito a ser discutido sobre a nutrição, uma vez que ela afeta diretamente o metabolismo; o sistema imunológico, a saúde mental e espiritual do indivíduo.

Mesmo encontrando dificuldades de aceitabilidade, a dieta vegetariana é seguida por uma grande parte das pessoas e vem ganhando espaço ao longo do tempo devido à busca das pessoas por mais saúde através da alimentação. Sendo ou não vegetariano, vale ressaltar que todas as dietas propostas pelo homem possuem regras e é de suma importância que sejam seguidas.

A dieta vegetariana deve ser balanceada, procurando equilibrar os alimentos em todas refeições, contendo uma variedade de cores, e buscando acrescentar os alimentos funcionais e orgânicos, reduzir o sal e levando em consideração o sexo, a idade, o peso, e a altura, visando atender as necessidades nutricionais do indivíduo e administrando as carências de vitamina B12, ferro, proteínas, gorduras e colesterol, aminoácidos essenciais e fibras, que de fato existem ao adotar a dieta vegetariana e principalmente na gravidez, lactação e período de crescimento.

Atualmente existem profissionais na área de saúde para orientar os interessados na adesão da dieta, e para realizar parcerias para estudar os benefícios da dieta vegetariana, dos alimentos de origem vegetal e a resistência dos adeptos por essa alimentação em relação a diversas doenças como obesidade, artrite reumatóide e síndrome nefrótica, cardiovascular, hipertensão, aterosclerose, osteoporose, câncer, diabetes e outras.

Os Adventistas do Sétimo Dia evidenciam os benefícios a saúde de uma dieta vegetariana, comprovando entre seus membros, dados epidemiológicos, que indicam taxas menores de diabetes não insulino-dependente, câncer de cólon e de mama e doença cardiovascular e da vesícula biliar. Entretanto, os dados não são suficientes para provar que uma dieta onívora, planejada de acordo com as diretrizes 
recomendadas e combinada com um estilo de vida saudável, não é igualmente benéfica (KRAUSE,K, 1998).

De acordo com CORAÇÃO DE QUEM NÃO COME CARNE BATE MUITO BEM (2002), em estudo de Guimarães (2002), foram avaliadas 146 pessoas com idade entre 20 e 55 anos divididas em três grupos: vegetarianos, semivegetarianos, (consomem carne de uma a três vezes por semana) e onívoros (comem de tudo inclusive carne diariamente). Compararam-se os resultados de vários exames, e constatou-se que $41,5 \%$ dos onívoros apresentaram hipercolesterolomia (aumento da quantidade de colesterol no sangue), contra $21,5 \%$ dos vegetarianos. E 21,9\% dos onívoros apresentaram alterações na pressão arterial e nenhum vegetariano apresentou alteração. Evidenciando que "os vegetarianos estão menos expostos a fatores de risco para doenças cardiovasculares, como colesterol e pressão alta, que aqueles que comem alimentos de origem animal".

\subsection{ECOLÓGICA}

Para os ecologistas, a dieta vegetariana é a opção mais adequada. E para os vegetarianos, a ecologia é um dos diversos fatores que merecem extrema atenção.

Esta preocupação não se restringe somente ao fato de se preservar e amar a natureza, mais sim encontrar mecanismos que controlem, solucionem e eliminem as causas de inúmeros problemas que possam dificultar o equilíbrio do ecossistema.

O alimento é um fator necessário desse enorme sistema e de extrema importância, pois está claro que tudo e todos dependem de alimentos e só é alcançado a qualidade desses alimentos se todos os subsistemas estiverem trabalhando juntos, corretamente e equilibradamente. Um depende do outro, como uma grande organização.

Um dos mecanismos utilizados é o desenvolvimento sustável que justamente procura alternativas para aproveitar os recursos naturais, o trabalho humano e a tecnologia de uma determinada área ou região, de maneira que não agrida o meio ambiente e que sejam obtidos resultados favoráveis para a economia e a preservação e equilíbrio do meio ambiente.

A preocupação com a qualidade dos alimentos e sua importância para a sobrevivência dos seres vivos e do meio ambiente, está relacionado com os outros 
fatores. Não se pode alcançar a qualidade da alimentação sem estudar as ligações com a qualidade e equilíbrio do meio natural de que provém e se desenvolve. Por tudo isso, os ecologistas e os vegetarianos se dedicam estudando, trabalhando e orientando a população com relação à agropecuária, agricultura, piscicultura, genética, poluição, efeito estufa, água e no combate à fome através da utilização correta das áreas de plantio, a preservação das espécies a defesa da exclusão da carne animal na alimentação, devido ao grande impacto ambiental causado pela agropecuária (TUDGE, 2002).

"O rebanho bovino é responsável por menos 12\% do gás metano (uma das substâncias que mais influencia no aumento da temperatura no planeta _ efeito estufa) liberado para o meio ambiente" (WINCKLER,1997))

Segundo o Wordwatch Institute, alimentar a população mundial atual com uma dieta baseada no estilo americano requereria 2 1/2 vezes a quantidade de grãos produzidos no mundo para todos os fins. Alimentar 8 a 14 bilhões de pessoas futuramente seria impossível de acordo com o estilo americano que sugere consumir 220 gramas diários de carne é gerada a partir do consumo de grãos, pois para produzir um quilo de carne de gado seria necessário $7 \mathrm{~kg}$ de cereais e soja, para produzir carne de porco 2,7 kg e para produzir carne de aves e ovos, são 1,3 quilos.

\subsection{ECONÔMICA}

Dado fornecido pelo IBGE (Instituto Brasileiro de Geografia e Estatística) e técnicos em agricultura (Instituto de Planejamento e Economia Agrícola de Santa Catarina, Instituto Cepa/SC), concluiu que um boi precisa de 3 a 4 hectares de terra e produz em média 210 quilos de carne, no período de 4 a 5 anos. No Brasil, ao mesmo tempo e na mesma quantidade de terra, colhe-se em média 19 toneladas de milho; ou 32 toneladas de soja ou 23 toneladas de trigo, além de poder obter 2 a 3 safras por ano destes cereais combinados, aumentado assim o volume de produção. Criando-se bois nos 3,5 hectares e nos 4,5 anos em média, ter-se-ão 39 quilos de proteínas. No entanto, plantando arroz nesta mesma quantidade de terra e no mesmo período ter-se-ão 1.520 quilos de proteínas. Um homem de 70 quilos consome cerca 70 gramas de proteína por dia, tomando por referência a proteína contida no arroz (8\%), comparando-a a da carne (18\%), criando gado haverá proteínas durante um ano e meio e plantando arroz, haverá proteína por 60 anos. 
Assim é mais barato adquirir proteínas através do reino vegetal do que no reino animal. (WINCKLER,1997)

Um outro fato relevante é que além do gado produzir menos alimentos ainda consome grande quantidade de cereais e pastos, visto que $85 \%$ do milho produzido no Brasil destina-se à alimentação de animais. (WINCKLER,1997)

\section{TIPO DE VEGETARIANISMO}

\subsection{Vegetarianos}

Para a IVU, União Vegetariana Internacional, "o vegetarianismo inclui o veganismo e define-se como prática de não comer carne, aves ou peixe ou seus subprodutos, com ou sem uso de laticínios e ovos."

\subsection{Veganismo}

O veganismo tem sido seguido por algumas pessoas em todos os tempos da história da humanidade, mas só recentemente os adeptos do veganismo foram denominados como VEGAN para serem distinguidos dos vegetarianos tradicionais, tornando-se uma sociedade.

A primeira sociedade vegan foi fundada em 1944 na Inglaterra, por questões éticas ao longo do tempo mais de 50 sociedades foram criadas em todo o mundo. Em 1960, H.Jay Dinshah, fundou a Sociedade Vegan Americana, onde enfatizava as questões de saúde. O movimento vegan pode ser considerado radical já que além de se tratar de uma questão alimentar é também filosófica e ética. Um vegan não se alimenta de nenhuma carne, de mel de abelha e nenhum alimento ou derivado de animal e não usa produtos como: a lã, couro, peles, ou roupas ou móveis, artesanatos, sabões ou cosméticos, escova feita de cabelos, travesseiros de penas e muitos não vão ao cinema, pois a película da tela possui gelatina. Alguns indivíduos vegan, inclusive, não se submetem à vacinação ou soro feitos de animais ou drogas que foram testadas em animais.

A Sociedade Britânica define o Veganismo da seguinte maneira: "Veganismo é uma forma de vida que exclui todas as formas de exploração e crueldade contra o 
reino animal. Inclui o respeito por todas as formas de vida. Isto se aplica no uso da prática de viver somente de produtos derivados do mundo vegetal".

Nesta categoria, os seguidores se sentem responsáveis em preservar os recursos naturais, buscando caminhos para manter o solo e o reino vegetal saudável e usar corretamente os materiais da terra, pois acreditam que as atitudes dos seres humanos influenciam na existência e tipos de vida do planeta.

\subsection{Lacto-vegetariana}

Esta dieta evita o consumo de ovos, que para os adeptos da dieta, significa a interrupção de um processo de vida. Segundo Bontempo (2002) “...os ovos hoje consumidos no mundo inteiro raramente possuem vida de fato, pois não são galados, ou seja, não têm mais energia vital. Seu consumo é bastante prejudicial à saúde por ser rico em antibióticos, toxinas, ácidos graxos saturados (colesterol...), hormônios, etc."

\subsection{Ovo-lacto-vegetariana}

Esta dieta admite o consumo de ovos, alimentos vegetais, leite e seus derivados, como a manteiga, requeijão, queijo e iogurte, evitando que ocorra deficiência de proteínas. Alguns ovolactovegetarianos são conscientes da importância de se consumir alimentos integrais e orgânicos, mas existem alguns que consomem também alimentos industrializados e o açúcar refinado.

\subsection{Ovo-vegetariana}

Os seguidores desta modalidade alegam que o consumo de ovos é permito porque a ave os botaria mesmo se eles não fossem utilizados na alimentação humana, mas não admitem o consumo de leite e derivados. 


\subsection{Crudívora}

Nesta dieta só se admite alimentos crus, sem a necessidade do fogo e do sal. Baseia na idéia de o alimento só deve ser consumido conforme a natureza os fornece.

O crudivorismo aceita as frutas, verduras, raízes, brotos, alguns tubérculos e cereais como a aveia, o trigo (triguilho picado, broto, etc). Prezam a beleza e a apresentação dos pratos, procurando deixá-los bonitos, coloridos e saborosos.

Os adeptos acreditam que quando um alimento é exposto ao cozimento e ao sal, perdem a sua energia vital, as enzimas e outras de suas propriedades nutricionais.

A alimentação natural recomenda dietas cruas como tratamento de doenças, pois possuem ação oxigenantes, revitalizantes, purificantes e adstringentes.

\subsection{Frugívora}

É a modalidade que admite apenas o consumo de frutas, podendo ser cozidas ou cruas. Algumas vertentes consomem cereais integrais, crus ou cozidos, pois os consideram como pequenos frutos. E evitam o uso de sal. Esta dieta está baseada a partir de observações bíblicas, antropológicas, antropométricas e na teoria da evolução de Darwin.

\subsection{Macrobiótica}

O termo "macrobiótica" tem origem grega "macro" que significa largo ou longo, e "bio" que significa vida. Logo, a macrobiótica é a arte e a ciência da saúde e da vida longa.

A macrobiótica se baseia em estudos das interações entre os seres humanos com os alimentos, o estilo de vida e o meio ambiente.

A macrobiótica, partindo de princípios concebidos por filósofos, estudiosos e físicos, ao longo da humanidade, foi citada primeiramente por Hipócrates, considerado o pai da medicina ocidental. 
No final do século XIX, o médico japonês chamado Sagen Ishizuka, tratava diversas doenças através de uma dieta alimentar composta por cereais integrais e legumes.

O filósofo e escritor americano com ascendência japonesa George Ohsawa sofrendo de tuberculose, adotou a dieta proposta pelo Dr. Ishizuka e acreditou ser ela a responsável por sua cura. A partir daí, George Ohsawa, publicou diversos trabalhos em japonês, inglês, e francês, onde foram combinadas as tradições macrobióticas dos ocidentais com a tradicional medicina oriental, datados de mais 5.000 anos (Pereira, 1987).

Atualmente o discípulo de George Ohsawa, o mais importante representante da alimentação macrobiótica principalmente nos Estados Unidos, chama-se Michio kushi. Ele se baseia na filosofia do Princípio Único e da Ordem do Universo. Michio publicou mais de cem livros e fundou o Kushi Institute, em Becket, Massachusetts, EUA.

Algumas práticas tradicionais incluem o consumo de cereais e grãos integrais, verduras, frutas e legumes frescos. Procuram o aumento de variedade dos alimentos e dos métodos tradicionais de cozimento.

A macrobiótica possui estreita relação com a medicina chinesa, que oferece legado baseado na filosofia taoísta, segundo a qual, existem na natureza duas forças opostas que se complementam buscando o equilibrando, harmonia e saúde entre o corpo e o espírito. O Yin é a força feminina e o Yang, a força masculina.

Os macrobióticos procuram através dos alimentos um aumento do bem-estar físico buscando combinar os alimentos para que a alimentação esteja equilibrada. Como os alimentos são oferecidos pela natureza, logo, eles possuem as forças yin e yang. Mas a macrobiótica determina que devem ser ingeridos apenas os alimento compostos das duas forças, que são chamados de alimentos neutros. E não ingerir os alimentos que predominam uma única força. Existem também os alimentos que não possuem as forças tão marcantes, eles são considerados alimentos intermédios. 


\subsection{Variações do vegetarianismo}

O vegetarianismo é definido como sendo uma prática alimentar que restringe a carne animal de sua alimentação, independentemente da existência de várias categorias, onde o indivíduo opta pelos alimentos que devem restringir.

Isto favorece aqueles indivíduos que consomem carne animal, mesmo que sejam somente carnes brancas e ou vermelhas esporadicamente, mas que sejam apreciadores por uma alimentação baseada em vegetais, cereais, produtos orgânicos, integrais, que são classificados como alimentação natural, integral ou light, possam se considerar vegetarianos. Para classificar esses indivíduos, são usados os seguintes termos:

Semivegetarianos: São os indivíduos que comem menos carne que a média das pessoas.

Pseudovegetariano: É um termo usado por aqueles que se dizem vegetarianos, mas na verdade são semivegetarianos ou piscitarianos.

Piscitarianos: Indivíduo que consome somente a carne de peixe. Muitos evitam técnicas agroindustriais.

Independentemente do tipo de dieta seguida e dos valores que levam as pessoas a diversificarem sua alimentação, a preocupação com a saúde parece ser um dos critérios mais relevantes nas escolhas. Atualmente com a crescente busca pela qualidade de vida em decorrência das descobertas da ciência defendendo a prevenção de doenças e das espécies e com a facilidade de acesso às informações, os indivíduos sentem-se quase que obrigados a buscar alternativas saudáveis para resistirem às conseqüências negativas advindas da vida moderna. Não somente por uma questão sugestionada, mas por uma conscientização de que os antigos hábitos da sociedade, condutas e princípios que se perderam ou foram esquecidos, devem ser respeitados e seguidos, conciliando os benefícios da ciência com uma rotina de vida baseada na prevenção da saúde. 


\section{METODOLOGIA}

\section{Materiais}

Para a realização da pesquisa foram identificados, por meio da lista de endereços, oito (8) empreendimentos gastronômicos que oferecem alimentação vegetariana, localizados na Asa Norte, Plano Piloto, Brasília-DF.

\section{Método}

Este é um estudo do tipo exploratório, estruturado e participante.

Um questionário (anexo II) foi desenvolvido em janeiro de 2004 para traçar o perfil da clientela atendida pelos restaurantes.

No mês de março de 2004 foram aplicados 184 questionários, representando 15\% da clientela atendida. Esse número total de clientes foi fornecido pelos donos dos estabelecimentos. Para a obtenção da quantidade de questionários a serem aplicados, tomou-se a freqüência média de clientes em cada estabelecimento.

Os clientes foram abordados para a entrega do questionário de forma aleatória, quando se encontravam no salão do restaurante e aceitavam participar da pesquisa. Foram orientados quanto ao objetivo da pesquisa e preenchimento do questionário.

O instrumento aplicado constitui-se de um questionário auto-administrado, composto de nove (9) questões objetivas (ver anexo II). Os dados foram analisados em planilhas do programa Microsoft Excel, assim como a elaboração dos gráficos ilustrativos. 


\section{RESULTADOS E DISCUSSÃO}

A figura 1 mostra que a população investigada apresentou uma predominância de indivíduos do sexo feminino, perfazendo um total de 57\% da amostra total (104 mulheres), enquanto a população masculina contribuiu com 43\% (80 homens) do total da população em estudo. Visto que em Brasília, segundo as estimativas da POPULAÇÃO Residente de março de 2004, realizado pela DATASUS (Tecnologia da Informação a Serviço da SUS), há maior incidência do sexo feminino com um número de 1.164 .958 indivíduos $(52,15 \%)$, enquanto a população masculina é de 1.068.656, observa-se que a amostra está compatível à realidade da cidade.

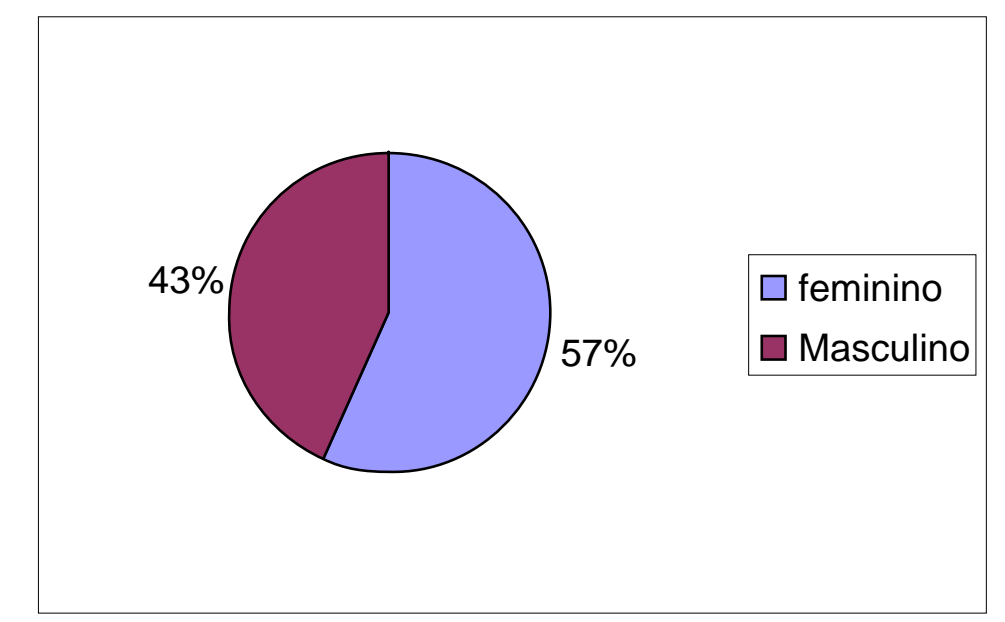

Figura 1 - Classificação da amostragem segundo sexo, 2004.

Pela figura 2, verifica-se que a maior da parte da população investigada encontra-se entre a faixa etária de 31-40 anos, contribuindo com um percentual de $30,3 \%$ do total da amostra. Um estudo realizado no refeitório vegetariano da UnB, apresentou 55\% entre a faixa etária de 20-24 anos, evidenciando que se trata de um estabelecimento constituído em maioria pelo público jovem (Teixeira, 2003) . 


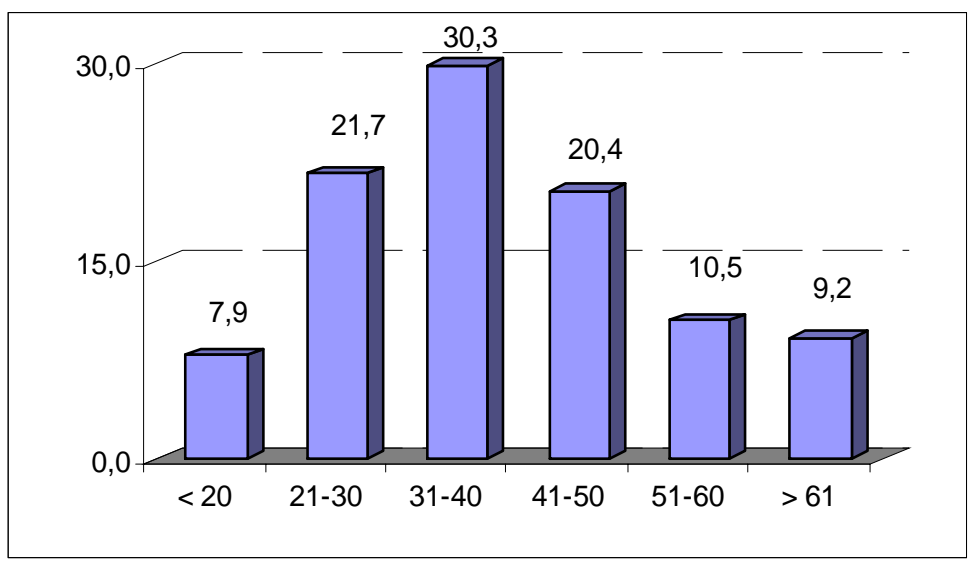

Figura 2 - Classificação da amostragem segundo faixas-etárias, 2004.

Ao analisar a amostra segundo o seu padrão alimentar, verificou-se que a maior parte da clientela (43\%) é considerada semivegetariana, pois além de manterem uma dieta baseada nos princípios do vegetarianismo, consomem carnes de origem animal, mesmo que esporadicamente. Os indivíduos vegetarianos participaram em $29 \%$ e os onívoros, indivíduos que não possuem restrições alimentares, com $28 \%$ do total de amostras.

Classificando a opção alimentar segundo o sexo (figura 3), verificou que $45 \%$ da população masculina e $41 \%$ da feminina são semivegetarianos. No caso dos vegetarianos, também o sexo masculino está em maior concentração com 30\% contra $28 \%$ de mulheres. Mas entre a categoria de onívoros, as mulheres aparecem em maior concentração do que os homens, com $31 \%$ e os homens com $25 \%$.
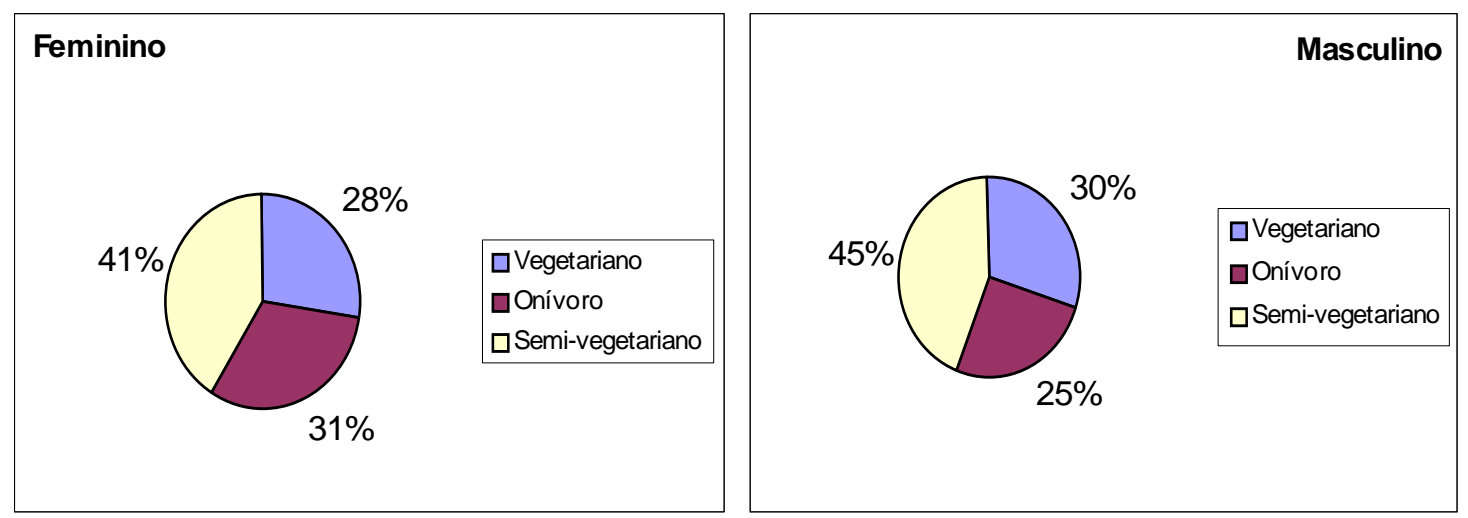

Figura 3 - Classificação da opção alimentar, segundo o sexo, 2004. 
Com relação à freqüência dos clientes nos restaurantes vegetarianos, observase que $25 \%$ da população entrevistada se alimentam pelo menos uma vez por semana no restaurante, mas está claro que não existe uma grande diferença entre a freqüência de clientes que visitam 5 vezes por semana 20,7\%, com os que visitam com menor freqüência (Figura 4).

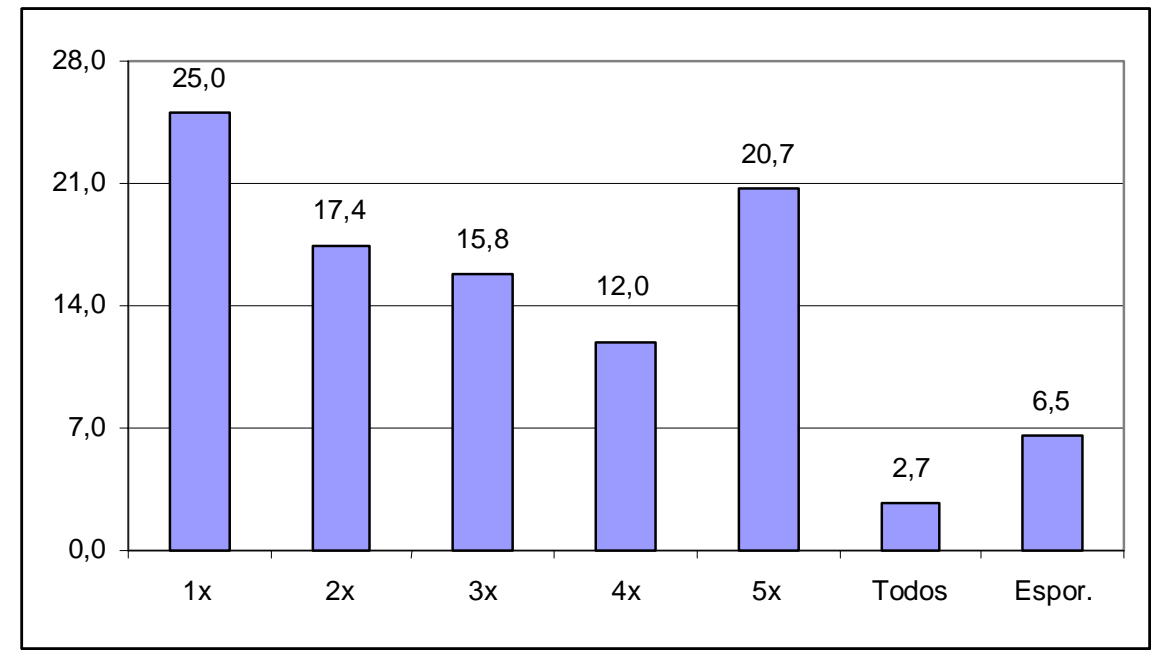

Figura 4 - Analise da freqüência da amostra total nos restaurantes, 2004

Usando a média ponderada, alcançou-se a freqüência geral nos restaurantes dos diferentes tipos de clientes, ou seja, os que estão classificados de acordo com a opção alimentar.

Nota-se que a freqüência geral nos restaurantes é maior entre os semivegetarianos, correspondendo a 43\% das visitas, coincidindo com a maior concentração de indivíduos com esta opção alimentar pesquisados nos restaurantes. Como era de se esperar, a freqüência dos onívoros foi a menor (23\%) nesse tipo de restaurantes. 


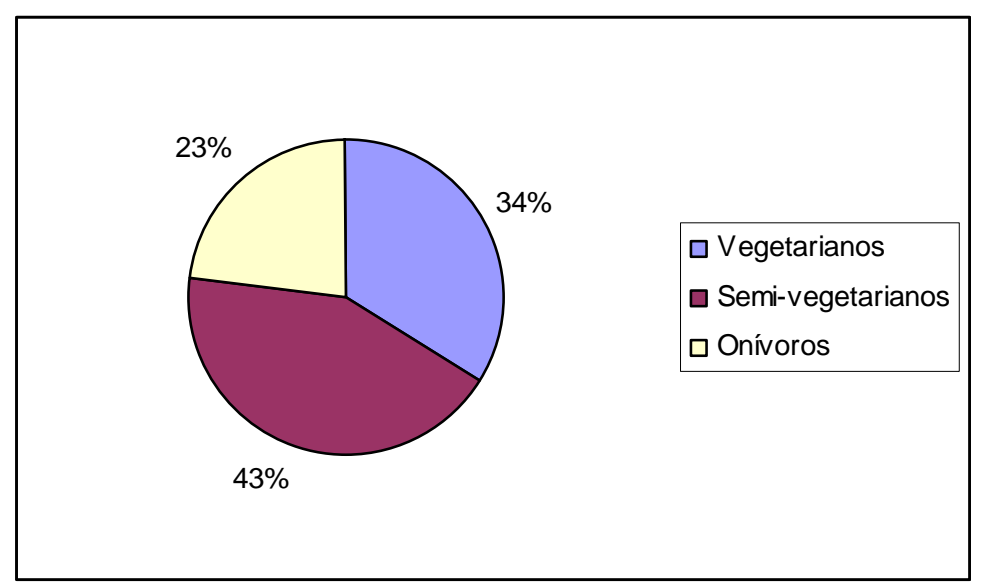

Figura 5 - Classificação geral de freqüência da amostra segundo a opção alimentar nos restaurantes, 2004.

A figura 6 demonstra individualmente a amostra de indivíduos segundo sua opção alimentar, e a sua freqüência nos restaurantes. Os resultados permitem concluir que $36,5 \%$ dos indivíduos onívoros marcaram sua freqüência no restaurante pelo menos uma vez na semana: $21 \%$ dos semivegetarianos, com 2 vezes por semana, e $28 \%$ dos vegetarianos de 5 a 7 vezes por semana, significando que dentro da amostra de vegetarianos, eles freqüentam mais vezes os restaurantes do que as outras amostras.

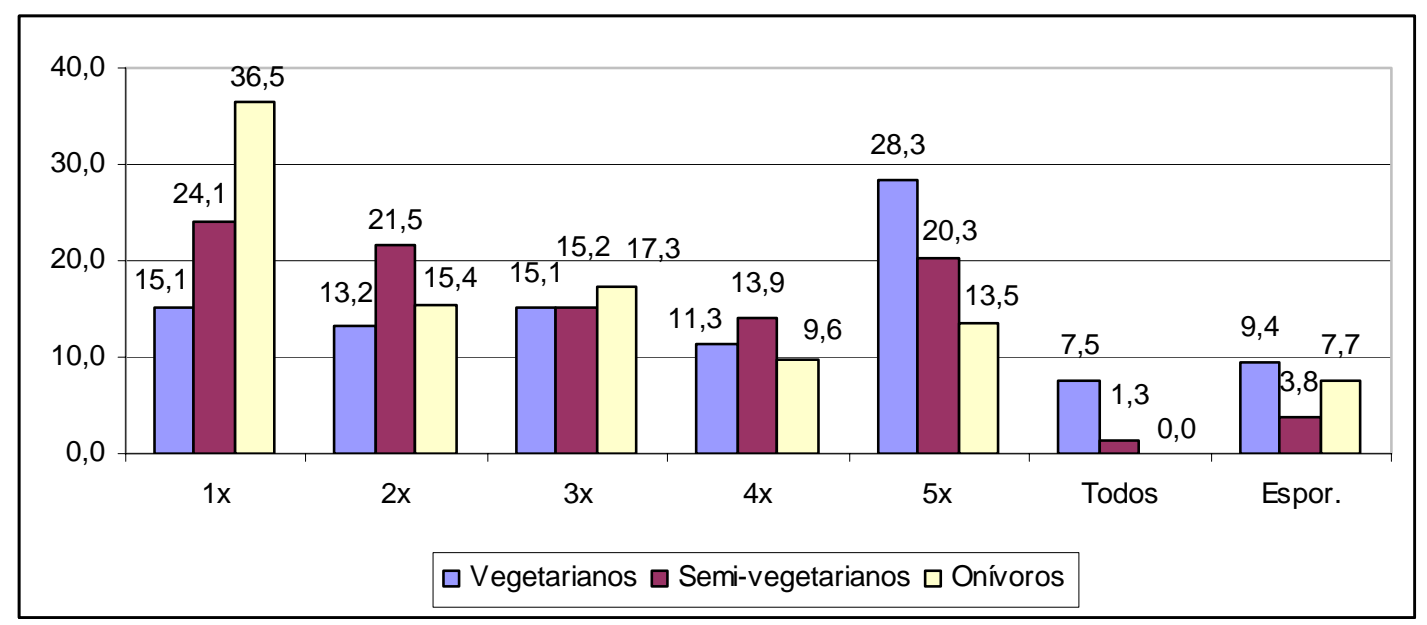

Figura 6 - Comparação da freqüência da amostra segundo a opção alimentar, 2004. 
Sabendo que os vegetarianos contribuem com 29\% do total de indivíduos pesquisados, verificou-se que dentro deste universo, 38\% dos indivíduos adotam a dieta Lacto-ovo-vegetariana. 32\% dos indivíduos não definiram em qual categoria se encontravam, marcando somente a opção VEGETARIANO. A opção Lactovegetariana encontra-se com $17 \%$ de adeptos. Os indivíduos que se consideram macrobióticos aparecem somente em 9\% dos resultados, os Vegans com 4\%, visto que este número não apresenta significância e demonstra que esta categoria não é expressiva entre a população investigada. O mesmo pode ser afirmado com as categorias Crudívora e Frugívora, pois não foi registrado por nenhum indivíduo pesquisado (Figura 7).

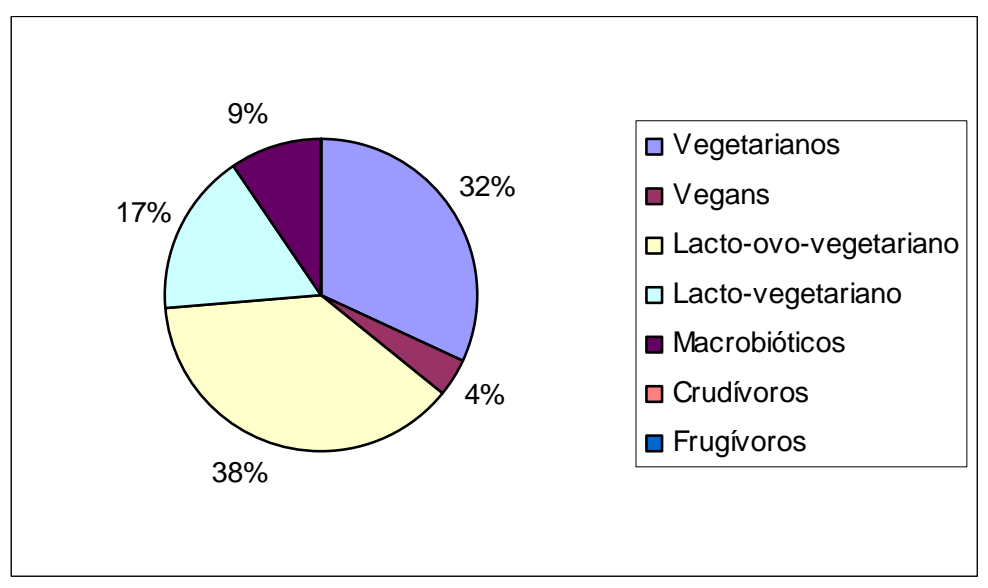

Figura 7 - Classificação da amostragem segundo a opção alimentar vegetariana, 2004.

Com relação aos motivos que justificam a adesão pela alimentação vegetariana, os clientes entrevistados, marcaram várias opções presentes no questionário. A opção "d" que acredita ser uma alimentação saudável, representou $80 \%$ das respostas seguido da opção "e" com 30\%. As demais opções, não chegam a $10 \%$ do total (Figura 8). Para facilitar a análise, as opções foram transformadas em escalas.
a) Religiosa
b) Ético
c) Econômico
d) Acredita ser uma alimentação saudável
e) Sabor
g) Ecológico
f) Recomendação Médica
h) Outros 


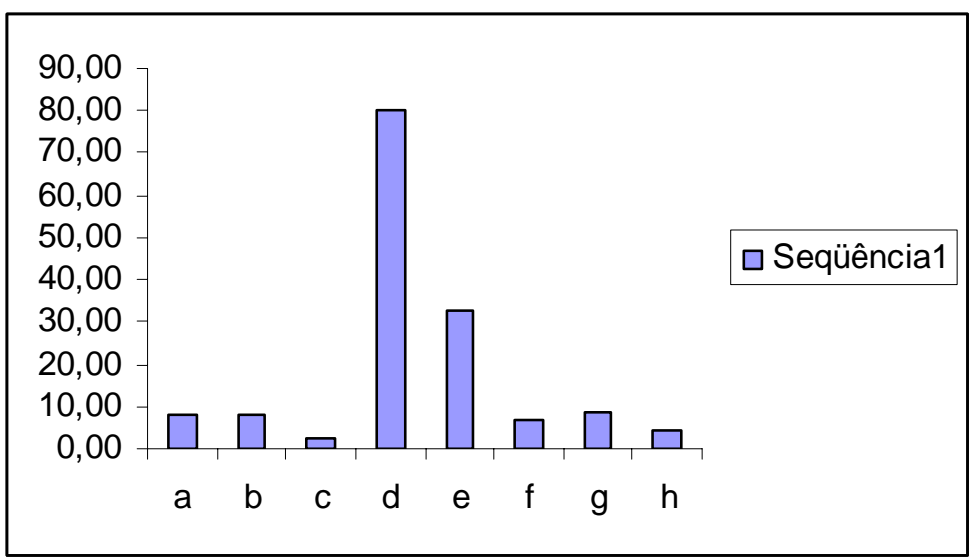

Figura 8 - Classificação da amostragem segundo as opções que justificam a escolha pela alimentação vegetariana, 2004.

Foi investigado ainda, dentro da amostra de indivíduos vegetarianos, o tempo de adesão pela dieta vegetariana. O maior índice alcançado foi o de 10 a 20 anos representando $34 \%$ do total, seguido por $26 \%$ de indivíduos que adotaram a dieta há mais de 20 anos (Figura 9).

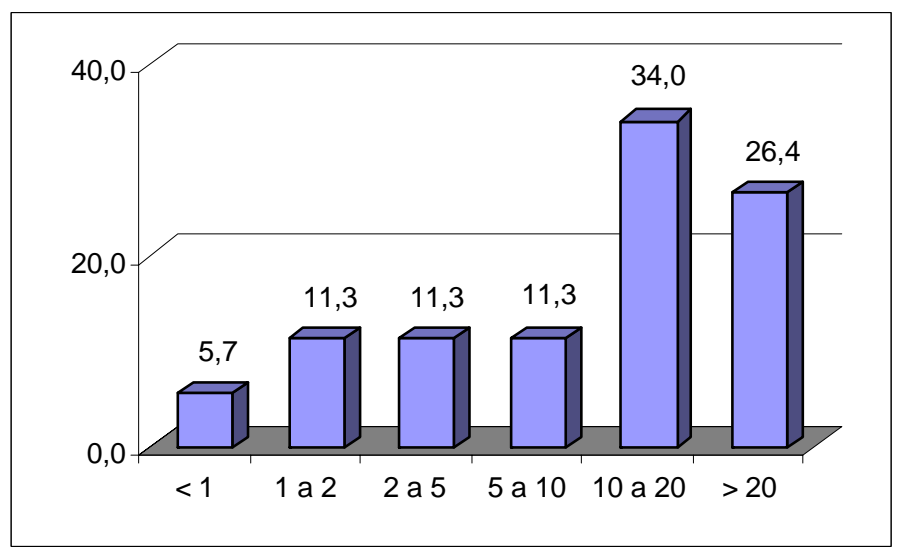

Figura 9 - Classificação da população vegetariana em relação ao tempo de adesão, 2004.

Evidencia-se que a maior parte dos indivíduos marcaram a opção "d" que representa a busca da saúde através da alimentação, na questão 5 do questionário; 177 indivíduos responderam que notaram benefícios com este tipo de alimentação, colaborando com o percentual de $96 \%$. 
A pesquisa também questionou se os clientes procuram balancear os alimentos com suas propriedades nutricionais a fim de alcançarem uma alimentação adequada para saúde e bem estar (questão 6). Os resultados obtidos mostram que foram 88\% de respostas foram afirmativas, mas que 64\% dos indivíduos entrevistados, não possuem orientação nutricional. Um fato importante é que tais indivíduos não possuem acompanhamento nutricional por profissionais de saúde, mas procuram se informar de forma indireta, visto que $88 \%$ combinam sua alimentação. O que não se pode afirmar através deste levantamento é que esses indivíduos se alimentam corretamente, mesmo que tenham alcançado benefícios com a alimentação. Os indivíduos que responderam que possuem orientação nutricional, correspondem a $36 \%$.

Um outro dado levantado na pesquisa que demonstra o interesse dos clientes, é a preocupação em obter uma alimentação saudável. 90\% dos entrevistados, vegetarianos ou não, responderam que consideram importante que os restaurantes identifiquem o cardápio de acordo com as categorias vegetarianas, tratando respeitosamente o consumidor, visto que existem indivíduos com restrições alimentares. Além disso, as informações nutricionais, que atualmente encontra-se em processo de legalização, são importantes para a escolha do estabelecimento.

Um outro objetivo da pesquisa foi demonstrar o custo benefício em se alimentar em restaurantes, comparando o valor cobrado com a qualidade do cardápio e atendimento oferecido. Os dados obtidos permitiram concluir que $80 \%$ dos indivíduos consideraram o valor compatível com o que é oferecido, destacando que existem diferenças quanto ao valor, a variedade de preparações, estrutura física e atendimento entre um estabelecimento e outro. 


\section{CONCLUSÃO}

Conclui-se que o perfil da clientela que freqüenta os restaurantes vegetarianos da Asa Norte, Brasília DF, é composta basicamente por indivíduos do sexo feminino, entre a faixa etária de 31- 40 anos, que estão classificados como semivegetarianos. Os $29 \%$ de indivíduos vegetarianos dentro do seu universo de amostras, foram considerados freqüentadores assíduos, juntamente com os semivegetarianos que manifestaram posições conscientes e favoráveis quanto à alimentação saudável, a partir de parâmetros nutricionais modernos.

O objetivo da pesquisa foi alcançado, porém observa-se uma necessidade de uma possível continuidade deste estudo a fim de emitir um diagnóstico com resultados significativos. Pressupondo que na Europa e nos EUA os vegetarianos somam a $10 \%$ da população e no Brasil, mesmo não havendo dados significativos quanto ao número de adeptos, mas estimativas através de números de filiados e participantes de organizações, palestras, congressos que estão envolvidos na divulgação do vegetarianismo e qualidade de vida, pela quantidade de turistas estrangeiros, pelo número de solicitações por produção de pratos vegetarianos em restaurantes convencionais e pelos números de restaurantes vegetarianos, é possível aver um crescimento de indivíduos interessados e preocupados em adquirir novos hábitos alimentares aliados com o bom gosto e segurança das preparações.

O mercado gastronômico propõe que a cozinha vegetariana sofra uma tendência de transformação. Ela vem evoluindo e adquirindo influências de várias regiões do mundo e adequadas ao ritmo de vida atual. Exigi-se o uso da criatividade e atenção com a estética, harmonia, coloração e com preparações práticas e rápidas, procurando aliar o conhecimento teórico e prático, garantindo a qualidade nos procedimentos de manipulação, produção e distribuição dos alimentos.

Um estudo mais aprofundado seria interessante para demonstrar o nível de satisfação da clientela em relação à qualidade dos serviços oferecidos pelos estabelecimentos e a preocupação dos proprietários em atendê-los. 


\section{REFERÊNCIA BILIOGRÁFICA}

AZEVEDO, A.A.C. Orientação alimentar para naturistas. Salvador: Deva Publicações, 1994.

BONTEMPO, Márcio. Alimentação para um Novo Mundo: A consciência ao se alimentar como garantia para a saúde e o futuro da vida na terra. Rio de Janeiro: Record, 2003.

BONTEMPO, Márcio. Suplementos nutricionais e produtos naturais. São Paulo: Best Seller, 1997.

BORGES, Kátia Nogueira. Sabor com Saúde: um guia de alimentação vegetariana. São Paulo: Ground, 2003.

CASCUDO, L.C. Antologia da alimentação no Brasil. Rio de Janeiro: Livros Técnicos e Científicos Editora, 1997.

CORAÇÃO de quem não come carne bate muito bem. Folha on Line. São Paulo, 1 de agosto de 2002.

Disponível em < http://www.uol.com.br/folha/equilibrio/beleza/ult559u50.shtml>

COURY, Soraya Vidya Terra. Nutrição Vital: Uma Abordagem Holística da Alimentação e Saúde. Brasília: livro da autora, 1999.

FERREIRA, Aurélio Buarque de Holanda. Minidicionário da Língua Portuguesa. 3. ed. Rio de Janeiro: Nova Fronteira, 1993.

FLANDRIN, Jean-Louis, MONTANARI, Massimo. História da Alimentação. São Paulo: Estação Liberdade,1998.

FONSECA, Marcelo, Traldi. Tecnologias Gerenciais de Restaurantes. 2. ed. São Paulo: SENAC, 2002.

GLEN BLIX, História do Vegetarianismo.Vibrant Life. V.8, n.15, p4, 15 de maio de 1992. Disponível em: <http://vegetarianismo.com.br/HistoriaDovegetarianismo.html> Acesso em 09/02/2004.

HIRSCH, Sônia. O mínimo para se sentir o máximo. Rio de Janeiro: 1993. 
KRAUSE,K.,Alimentos e Dietoterapia, 1998.

LYRA, Alberto. Doente: Ajuda o teu Médico: Normas de Alimentação e Vida Naturista. 2. ed. Rio de Janeiro: Record, 1958.

McGEE, Charles. Sobrevivendo à Tecnologia. Porto Alegre: L\&PM,1986.

MELINA, Davis e Harrison. Adieta saudável dos vegetais. Rio de Janeiro: Campus, 1998.

ORNELLAS, Leiselotte Hoe'schl. Técnica Dietética: Seleção e Preparo de Alimentos. 5. ed. São Paulo: Atheneu, 1988.

OXFORD COMPANANION TO PHILOSOPHY. Organização de Ted Honderich. OUP,1995.

Disponível em <http://www.criticanarede.com/fil_vegetarianismo.htm1> Acesso em 09/02/2004

PASSOS, Ardelita. Alimentação Natural ao Seu Alcance, 3. ed.

PEREIRA, Gilberto. A Cozinha Natural dos Trópicos. São Paulo: Sol Nascente, 1987.

POPULAÇÃO Residente do Distrito Federal em, 2004. DATASUS. Disponível em <http://tabnet.datasus.gov.br/cgi/deftohtm.exe?ibge/cnv/popdf.def> Acesso em 13/03/2004.

SANCHEZ, M. e SANCHEZ, M. Medicina nutricional. São Paulo: Pensamentos, 1995.

SENAC. DN. A História da Gastronomia. Rio de Janeiro: Senac Nacional, 1998.

SOUZA, Nádia Isabel. Aliment'arte: uma nova visão sobre o alimento e sua produção. São Paulo: Livraria Varela, 2001.

TEIXEIRA. Raquel Mara. Perfil da Clientela do RU - Refeitório Vegetariano. 2003. Monografia (Graduação Trabalho de Conclusão do Curso de Nutrição). Faculdade de Saúde - UNB, Brasília, 2003

TUDGE, Colin. Os Alimentos do Futuro. São Paulo: Publifolha, 2002.

UCHA. Culinária natural e vegetariana. São Paulo: Pensamentos, 1995.

WADE, C. Alimentos naturais para obter mais energia. Rio de Janeiro: Campus, 1995

WINCKLER, Marly. Vegetarianismo: elementos para uma conversa sobre. 2. ed. Florianópolis: Rio Quinze, 1997. 
Brasília, 26 de janeiro de 2004.

Senhor Proprietário,

Apresentamos a aluna dos Cursos de Pós-Graduação em Qualidade em Alimentos e Gastronomia e Segurança Alimentar da Universidade de Brasília, Milene Luccas Leite.

A referida aluna está desenvolvendo pesquisa qualitativa e quantitativa para a elaboração de monografia final de curso e solicitamos sua colaboração para a realização da mesma em seu estabelecimento comercial. O tema que será abordado é o Vegetarianismo, e terá como prioridade principal levantar o perfil da população que freqüenta os restaurantes naturais da Asa Norte.

Serão aplicados questionários com alguns clientes que freqüenta o restaurante e, os resultados serão encaminhados ao estabelecimento para que ajude na qualidade do serviço prestado. Todos os dados coletados não serão divulgados utilizando o nome do restaurante.

Agradecemos sua especial colaboração e colocamo-nos a sua disposição para outros esclarecimentos.

Atenciosamente,

Raquel Assunção Botelho

Coordenadora

Gastronomia e Segurança Alimentar 


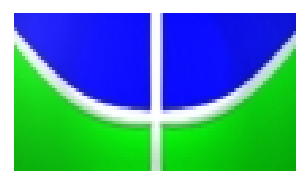

\title{
PREZADO CLIENTE:
}

Com objetivo de conhecer a clientela que freqüenta as unidades de alimentação de restaurantes vegetarianos, pedimos a gentileza de responder a pesquisa apresentada. Contando com sua colaboração para melhoraria dos serviços oferecidos.

\section{QUESTIONÁRIO}

\author{
Sexo: ( ) F ( ) M Idade: ___ Escolaridade ( ) 1 grau completo ( ) 1 grau incompleto \\ ( ) 2 grau completo ( ) 2 grau incompleto \\ Profissão: \\ ( ) 3 grau completo ( ) 3 grau incompleto
}

1.Qual a freqüência de utilização do restaurante?
( ) 1 vez na semana
( ) 4 vezes na semana
( ) 2 vezes na semana
( ) 5 vezes na semana
( ) 3 vezes na semana
( ) Todos os dias
( ) Esporadicamente

2. Sua dieta está baseada dentro de alguns grupos abaixo:

( ) Vegetariana - Não consome carnes de origem animal.

( ) Vegan - Não consome carnes e derivados, mel e nenhum tipo de produto de origem animal.

( ) Lacto-ovo-vegetariana - Consome leite e derivados ( iogurte, queijo) e ovos.

( ) Lacto-vegetariana - Consome leite e derivados.

( ) Macrobiótica - Consome grãos e cereais integrais.

( ) Crudívora - Consome somente alimentos crus.

( ) Frudívora- Consome somente frutas.

( ) Consome carnes brancas ( peixe e aves, frutos do mar)

( ) Pesco-vegetariano- Consome apenas peixe como fonte de carne

( ) Consome carnes vermelhas esporadicamente

( ) Onívoros - consome todos os tipos de alimentos.

3. Marque as opções que justifiquem a escolha pela alimentação natural
( ) Religioso
( ) Acredita ser uma alimentação saudável
( ) Sabor
( ) Ecológico
( ) Ético
( ) Recomendação Médica
( ) Outros
( ) Econômico

$$
\text { ( ) Recomendação Médica }
$$

4. Há quanto tempo adotou a alimentação natural
( ) Menos de 1 ano
( ) 1 a 2 anos
( ) 2 a 5 anos
( ) 5 a 10 anos
( ) 10 a 20 anos
( ) A mais de 20 anos
( ) Consume esporadicamente

5. Notou benefícios com este tipo de alimentação?

( ) Sim ( ) Não

6. Procura combinar os alimentos para que a refeição se torne balanceada?

7. Você possui orientação nutricional?

( ) Sim ( ) Não

8. Considera importante que os restaurantes identifiquem o cardápio de acordo

( ) Sim ( ) Não

vegetarianas e com informações nutricionais?

( ) Sim ( ) Não

9.Considera o valor cobrado pelo restaurante compatível com a qualidade do atendimento e do cardápio oferecido.

( ) Sim ( ) Não 
